\title{
Dialogue
}

\section{LAYING IT ON THE LINE: A DIALOGUE ON LINE ITEM VETOESAND SEPARATION OF POWERS}

\author{
H. JeFFERSON POWELL $†$ \\ JED RUBENFELD††
}

In this Dialogue, constitutional pundits Confident and Doubtful debate the $L$ ine Item $V$ eto $A$ ct of 1996 . They wrangle about the application of the A rticle I, $\S 7$ process to the A ct, the relevance of the legislative bargaining process to its constitutionality, and the merits of formalism and functionalism. As Confident becomes N o-L onger-SoConfident, D oubtful proposes a way to reconcile the seemingly irreconcilable "formalist" and "functionalist" Supreme Court decisions. $M$ arshalling the constitutional text for support, Doubtful argues that the Court should take a checks and balances approach to congressional delegations of power to the executive, while maintaining a rigorous separation of powers review of A rticle I powers.

A the time of the writing of this D ialogue, the $L$ ine Item Veto A ct was, as the prologue indicates, awaiting a pronouncement from the Supreme Court. In Clinton v. City of N ew Y ork, ${ }^{1}$ the A ct was invalidated. H owever, the Dialogue stands not only as a strong dissent to the majority's opinion in that case, but as a powerful argument for a new conception of formalism and functionalism.

\section{INTRODUCTION}

The L ine I tem $V$ eto $A \mathrm{Ct}^{2}$ is once again on its way to the Supreme Court of the $U$ nited States. Federal district judges have twice con-

$\dagger$ Professor of Law, Duke Law School; B.A. 1975, U niversity of Wales; M. Div. 1979, J.D. 1982, Y ale U niversity; A .M . 1977, Ph.D 1991, D uke U niversity.

†† Professor of Law, Y ale Law School; A.B. 1980, Princeton U niversity; J.D. 1988, H arvard U niversity.

1. 118 S.Ct. 2091(1998).

2. Pub. L. N o. 104-130, 110 Stat. 1200 (1996) (codified at 2 U .S.C. $\S \S 691,691 a-691 f, 692$ 
cluded that the A ct violates the Constitution's division of authority between Congress and the President. ${ }^{3}$ The Supreme Court dismissed the first case for lack of standing. ${ }^{4}$ A ssuming that the Court reaches the merits in the present case, Clinton v. City of N ew York, ${ }^{5}$ we suspect most observers find little reason to doubt that the Court will hold the A ct unconstitutional. ${ }^{6}$

Isn't that obviously the correct decision? The Line Item V eto A ct certainly looks unconstitutional, because it seems to derogate so palpably from the A rticle I, Section 7 lawmaking process and because the A ct seems to make the President a lawmaker. B ut what looks unconstitutional may not be unconstitutional. A careful analysis of the Section 7 and separation of powers issues suggests that the Line Item $\checkmark$ eto $A$ ct-either as written or with minor modifications-is not unconstitutional after all. Perhaps the confident critic of the A ct would

(Supp. II 1996)). [This A ct was invalidated by the Supreme Court after the completion of this D ialogue. See Clinton v. City of N ew Y ork, 118 S.Ct. 2091(1998)-E ds.]

3. See Byrd v. R aines, 956 F. Supp. 25 (D.D.C. 1997), appeal dismissed sub nom. R aines v. Byrd, 117 S. Ct. 2312 (1997); City of N ew Y ork v. Clinton, 985 F. Supp. 168 (D.D.C.), appeal docketed sub nom. Clinton v. City of N ew Y ork, 118 S. Ct. 1123 (1998). The A ct vests jurisdiction over challenges to its constitutionality in the District of Columbia court and provides for direct appeal to the Supreme Court from any decision on that issue. See 2 U .S.C. § 692 (Supp. II 1996).

4. See R aines v. Byrd, 117 S. Ct. 2312, 2317 (1997). In Raines, six M embers of Congress who had voted against the A ct brought suit, alleging that the A ct "unconstitutionally expands the President's power." Id. at 2315-16. The A ct specifically provides that "[a]ny M ember of Congress or any individual adversely affected by [the Act] may bring an action... on the ground that any provision of ... this part violates the Constitution." 2 U .S.C. § 692(a)(1) (Supp. II 1996). The Court, however, ruled that the plaintiffs had "alleged no injury to themselves as individuals" and that "the institutional injury they allege is wholly abstract and widely dispersed." Raines, $117 \mathrm{~S}$. Ct. at 2322. In a concurring opinion, J ustices Souter and G insburg expressly stated their view that private plaintiffs who would have benefited from provisions cancelled under the A ct would "likely ... have standing under A rticle III." I d. at 2325 (Souter, J ., concurring). J ustices Stevens and B reyer thought that the Raines plaintiffs had standing. See id. at 2326 (Stevens, J ., dissenting); id. at 2329 (B reyer, J ., dissenting).

5. A ppeal docketed, 118 S. Ct. 1123 (1998).

6. O ne member of the Court appears already to have concluded that the A ct is unconstitutional. See Raines, $117 \mathrm{~S}$. Ct. at 2327 (Stevens, J., dissenting) ("Given the fact that the authority at stake is granted by the plain and unambiguous text of A rticle 5 , it is equally clear to me that the statutory attempt to eliminate it is invalid."). On one ground or another, many commentators agree. See, e.g., M ichael J. G erhardt, The B ottom L ine on the L ine-I tem V eto A ct of 1996, 6 CORNELL J.L. \& PUB. POL'Y 233 (1997) (arguing that the A ct is unconstitutional because it redefines the constitutional term "bill," alters the balance of powers, and violates the delegation doctrine); L awrence $L$ essig, $L$ essons from a $L$ ine Item $V$ eto $L$ aw, 47 CASE W. RES. L. REV. 1659, 1661-63 (1997) (arguing that the A ct is unconstitutional because it violates the delegation doctrine); M ichael B. R appaport, V eto Burdens and the L ine Item V eto Act, $91 \mathrm{~N} \mathrm{w.}$ U. L. REV . 771, 772-73 (1997) (arguing that the A ct is unconstitutional because it burdens the President's veto power). 
do well to carefully consider the arguments of the A ct's doubtful defender.

C onfident: $L$ et's get one thing straight at the beginning: the Supreme Court has held that "[t]he fact that a given law or procedure is efficient, convenient, and useful in facilitating functions of government, standing alone, will not save it if it is contrary to the Constitution." So no arguments based on the supposed need for this monstrosity.

D oubtful: Y ou won't hear any from me. To tell you the truth, I have no idea whether the A ct is good or bad policy. For all I know, it may lessen the already too weak political constraints on congressional pork-barreling. But I quite agree: let's confine ourselves to constitutional arguments.

Confident: In that case there can be no doubt. A President may not pick and choose which provisions of a bill presented to him by Congress will be the law of the land. The Line I tem $V$ eto A ct empowers the President to sit as a censor of legislative actions and to rewrite the legislative bargains that Congress has struck. In effect, the President becomes the nation's chief lawmaker-which violates not only the most basic principles of separation of powers, but also the clear dictates of A rticle I, Section 7.

D oubtful: That certainly sounds unconstitutional.

Confident: I'll tell you something else: the A ct is indistinguishable as a practical matter from a law authorizing the President to pencil out provisions of a bill presented for his signature before signing it. A nd everybody knows that would be unconstitutional.

D oubtful: Y ou make me almost embarrassed to be doubtful. W ill you let me try to separate out the various arguments you're making, so that we can look at them one by one?

Confident: Certainly-although the arguments are highly interrelated.

7. IN S v. Chadha, 462 U .S. 919, 944 (1983). 
D oubtful: I can see that. H ere's what I propose. I always think it best to start with the constitutional text, so let's begin with your claim that the A ct violates A rticle I, Section 7. A fter that, we can discuss whether the A ct impermissibly allows the President to upset the legislative bargains struck in Congress. Then, we'll take up the idea that the A ct turns the President into a lawmaker, in violation of basic separation of powers principles. A nd finally, we'll return to your point about the A ct being functionally indistinguishable from a presignature line item vetoact. F air enough?

Confident: I'm confident.

\section{ARTICLE I, SECTION 7}

D oubtful: T ell me, then, exactly why the $L$ ine I tem $V$ eto $A$ ct violates A rticle I, Section $7 .^{8}$

Confident: W ith pleasure. E veryone knows that Section 7 gives the President only two options when presented with a bill. "[B]e the bill small or large, its concerns focused or diffuse, its form particular or omnibus, the President must accept or reject the entire thing, swallowing the bitter with the sweet." ${ }^{\prime \prime}$ In one of the modern Supreme Court's central separation of powers cases, the Chadha decision invalidating the one-H ouse legislative veto, the Court stated that "the prescription for legislative action in A rt. I, $\S \S 1,7$, represents the Framers' decision that the legislative power of the Federal government be exercised in accord with a single, finely wrought and exhaustively considered, procedure."10

8. U.S. CONST. art. I, § 7, cl. 2:

Every Bill which shall have passed the House of Representatives and the Senate, shall, before it become a Law, be presented to the President of the U nited States; If he approve he shall sign it, but if not he shall return it, with his Objections to that $\mathrm{H}$ ouse in which it originated, who shall enter the Objections at large on their J ournal, and proceed to reconsider it. If after such Reconsideration two thirds of that H ouse shall agree to pass the Bill, it shall be sent, together with the Objections, to the other House, by which it shall likewise be considered and if approved by two thirds of that $\mathrm{H}$ ouse, it shall become a Law.

9. LA URENCE H. TRIBE, A MERICA N CONSTITUTIONAL LAW § 4-13, at 265 (2d ed. 1988); see also The President's V eto Power, 120 p. O ff. L egal Counsel 128, 128-69 (1988) (concluding that neither text nor history nor analogy to judicial review supports the constitutionality of an inherent line item veto power).

10. Chadha, 462 U.S. at 951. 
The effect of the Line Item $V$ eto $A$ ct-indeed the very aim of the A ct-is to alter this "single, finely wrought and exhaustively considered, procedure." U nder the A ct, after the President has signed a bill presented to him by Congress, he has five days to "cancel" certain taxing and spending provisions upon his sole determination that such cancellation will "reduce the Federal budget deficit" and do no harm to "the national interest." ${ }^{11}$ If Congress wants to reenact the canceled provisions, both chambers must pass, by a majority vote, a "disapproval bill," ${ }^{12}$ which may itself be vetoed by the President, in which case the canceled provisions can become law only if re-passed by two-thirds votes in both the H ouse and the Senate. The A ct thus profoundly alters the process of lawmaking specified in the Constitution, a process which Congress and the President have followed without exception for 200 years.

The A ct's inconsistency with Chadha could not be clearer. In fact, the line item veto flouts the A rticle I, Section 7 process in the very same way that the legislative veto did. The legislative veto was unconstitutional because it enabled a single $\mathrm{H}$ ouse of Congress to make law through a mechanism that did not conform to the Constitution's requirements of bicameralism or presentment. ${ }^{13}$ In a parallel fashion, the Line Item $V$ eto $A$ ct is unconstitutional because it enables the President to make law through a mechanism equally at odds with bicameralism (in fact, neither House is involved in the President's exercise of the veto) and with presentment (the President exercises the line item veto outside the time period prescribed by Section 7 and in defiance of the all-or-nothing limitation on the constitutional veto power). In short, the A ct is a blatant attempt to give the executive a second, retail role in the lawmaking process, when the Constitution deliberately affords the President only one wholesale shot at shaping the law.

11. 2 U.S.C. § 691(a)(A )(i)-(iii) (Supp. II 1996). The A ct applies to "any dollar amount of discretionary budget authority," "any item of new direct spending," and "any limited tax benefit." Id. § 691(a)(1)-(3).

12. Id. § 691d.

13. See Chadha, 462 U.S. at 956-58. In a subsequent memorandum decision, the Court seemed to make clear that the holding of Chadha applies to two-House vetoes as well. See U nited States Senate v. FTC, 463 U .S. 1216 (1983) (mem.), aff'g Consumers U nion of U nited States, Inc. v. FTC, 691 F.2d 575 (D.C. Cir. 1982) (per curiam) (striking down Section 21(a) of the Federal Trade Commission Improvements A ct of 1980 , which provided that an FTC trade regulation rule should become effective unless both $\mathrm{H}$ ouses of Congress disapproved it). If anything, this strengthens the argument that, under Chadha, federal lawmaking must follow precisely the procedures ordained by A rticle I, Section 7. 
D oubtful: I'm very nearly convinced. There's just one doubt in my mind: I'm not sure that Chadha applies.

Confident: Of course Chadha applies. We're talking about A rticle I, Section 7. Chadha is the leading case.

D oubtful: $Y$ es, but as the Court acknowledged in that case, the first step in the analysis is to "establish that the challenged action ... is of the kind to which the procedural requirements of A rt. I, § 7 apply." ${ }^{14}$ Now, the procedural requirements of Section 7 cannot apply in any categorical way to action taken by executive branch officers, even if the action is what you and I would probably call "lawmaking." A ctors within the executive branch make law every day (for example, by enacting regulations) outside of the process set forth in A rticle I, Section 7. Chadha itself expressly states that such "lawmaking" by executive officers need not satisfy the requirements of Section $7 .{ }^{15}$ So, even if the President is engaged in "lawmaking" when he exercises the cancellation power conferred on him by the Line I tem $\mathrm{V}$ eto $\mathrm{A}$ ct, why would Chadha apply?

Confident: Because the Act directly intrudes upon the Section 7 process itself. The A ct has nothing to do with run-of-the-mill executive branch lawmaking within the confines of statutorily delegated authority. Instead, it directly intrudes upon the finely wrought constitutional process through which Congress and the President make the law of the land in the first place.

D oubtful: Y ou sound very persuasive. But you are too quick for a slow thinker like me. Y ou agree, if I have it right, that Section 7 is not violated every time Congress authorizes actors in the executive branch to enact regulations that have the force of law?

Confident: Certainly I agree. I'm not suggesting that the Constitution forbids properly constrained delegations of regulatory authority.

14. Chadha, 462 U.S. at 952

15. See id. at 953 n.16 ("Executive action under legislatively delegated authority that might resemble 'legislative' action in some respects is not subject to the approval of both Houses of Congress and the President for the reason that the Constitution does not so require."). 
D oubtful: A nd you agree that when we speak here of "actors in the executive branch," we include the President himself? In other words, if Congress authorized the President himself to render a decision that would bring into effect a new rule of law, you would not say that Section 7 had necessarily been violated?

Confident: No, within the broad limits of delegation doctrine, there would be no particular constitutional problem in permitting the President the rule making power often entrusted to inferior executive officers.

D oubtful: A II right. Then I think a great deal turns on the distinction you draw between what you call "run-of-the-mill executive branch lawmaking" and the "constitutional process through which Congress and the President make the law of the land." Do you mind if I ask you one or two questions about this distinction?

Confident: N ot a bit.

D oubtful: W ell, it seems to me that an important feature of what you call "run-of-the-mill executive branch lawmaking" is that it happens after the Section 7 process has been complied with. Is that right?

Confident: Q uite right.

Doubtful: So the crucial distinction is between presidential action that forms part of the Section 7 process itself, and presidential action that takes place only after law has already been properly made through that process?

Confident: I believe that's what I've said.

D oubtful: G ood. Then let's take the L ine I tem V eto A ct step by step. U nder the system the A ct establishes, the first thing that happens is that a bill containing provisions subject to the A ct is passed by a majority vote of both $\mathrm{H}$ ouses and presented to the President for his signature. Is there any violation of Section 7 at this point? 
Confident: Of course not. The violation occurs when the President vetoes particular provisions of the bill.

D oubtful: Perhaps. B ut you agree, then, that under the $A \mathrm{ct}$, the President is constitutionally presented with a bill. If he vetoes the bill in whole upon presentment, is there any constitutional problem?

Confident: $\mathrm{O}$ bviously not. The A ct doesn't purport to alter the constitutional rules governing what happens to a properly vetoed bill. A s I said a moment ago, the constitutional violation occurs only when the President signs the bill and then purports to veto particular provisions in it.

Doubtful: I'm glad you think so, but I think I ought to tell you that one scholar has found a constitutional problem just here. ${ }^{16} U$ nder the A ct, a vetoed bill that was later made law by a two-thirds vote of the House and Senate would apparently not be subject to the President's line item cancellation power. Therefore, this scholar argues, the Line I tem V eto A ct imposes an unconstitutional "burden" on the President's veto by taking away a power he would have had, just because he vetoed a bill. ${ }^{17}$ Personally, I don't find this "veto-burden" argument quite convincing, but unless you object, I will confine my remarks about this problem to a footnote.

C onfident: L et me ask one question. If this "veto-burden" problem is really a problem, could it be fully taken care of by a new Line Item $\checkmark$ eto $A$ ct of 1998, identical to the present one except that the new A ct would apply to all laws, whether passed with the President's signature or over his veto?

D oubtful: Y es. The "veto-burden" problem does not go to the constitutionality of the line item cancellation power itself.

C onfident: Then I'm not interested in it.

16. See R appaport, supra note 3 , at 772-73.

17. See id. 
D oubtful: Footnote it is. ${ }^{18}$ To pick up our thread: let's say, then, that there is no constitutional problem if the President vetoes the entire bill. Suppose now that he signs the bill. Is there a constitutional problem at this point?

Confident: $\mathrm{H}$ as the President done a line item veto or not?

D oubtful: We don't know yet. He has just signed the bill. The A ct gives him five days to exercise his cancellation power. But at the moment he signs the bill, is there a constitutional violation?

Confident: W ell I would have to say-actually, I'm not sure how to answer that question.

D oubtful: Perhaps I can help. A t the moment the President signs a bill, is the bill law?

C onfident: $\mathrm{Y}$ es, it certainly is. The Constitution says so. If the President signs a bill duly and properly presented to him, it becomes a law. ${ }^{19}$

D oubtful: I think so too. So it seems fair to say that to this point the Line Item $V$ eto $A$ ct fully satisfies the requirements of Section 7. A bill is passed by majority vote of both Houses; it is presented to the President for his signature. If he vetoes the bill, it is returned to the Congress for a potential supermajority bicameral override, but if he signs the bill, the bill is law. Fair enough to this point?

18. The A ct does not seem to "burden" a President's veto power any more than plea bargaining "burdens" a defendant's right to a jury trial. The A ct confers on the President a new power if he signs certain bills into law, but puts him in no worse a position if he vetoes (just as a plea offer confers on the defendant a benefit if he pleads guilty, but puts him in no worse a position if he goes to trial). A statute that read, "Whenever the President vetoes any bill, ten million dollars will be subtracted from the funds available to the executive branch," might be unconstitutional as a "veto burden." But the Line Item V eto A ct is in no way a generalized penalty on the veto power. It simply makes the President's unilateral cancellation power inapplicable when Congress has passed the subject law over the President's initial veto, a limitation consistent with the basic structure of A rticle I, Section 7, because Congress can always achieve any legislative results it wants (irrespective of the President's views) by a two-thirds vote in favor of that result in both chambers.

19. U.S. CONST. art. I, § 7, cl. 3. 
Confident: I suppose.

D oubtful: Y ou "suppose"?

Confident: W ell, something is troubling me, but I'm not sure what.

D oubtful: Something's troubling me, too, because if the A ct doesn't disturb the A rticle I, Section 7 process up to the point where a bill becomes law, then it's hard to see how the subsequent cancellation power that the A ct vests in the President can be said to disrupt the Section 7 process. Y ou said yourself that the crucial distinction was between presidential action that takes place after a bill has properly become law under Section 7, and presidential action that is part of the Section 7 process itself. But you agreed with me just now that the bill becomes law upon the President's signature, and at that moment the Section 7 process is complete. The relevant precedent, therefore, is not Chadha; it is the body of case law prescribing the rules that pertain to congressional delegations of what looks like legislative power to the executive branch. A nd of course that body of case law imposes very few limitations. In fact, if you like, I can cite you a long line of cases upholding a presidential power to cancel or to suspend provisions of extant law, and I can cite you an even longer line of statutes, old and new, entrusting just such a power in the President. Care to hear my authorities? ${ }^{20}$

Confident: No, thanks. I can now see even better than I could before why the A ct is unconstitutional, and it is a Section 7 problem, after all. The A ct violates the mandatory phrase "shall . . . become a L aw." The Constitution says that a bill signed by the President "shall . . . become a Law," and you were just assuming that when he signs a bill, it is law. But that's not really true. U nder the A ct, a bill signed by the President is law only if he chooses not to cancel any portion of it. E very provision in a signed bill must become law upon the presidential signature, but the A ct purports to give the President a way of avoiding that constitutionally mandated result.

D oubtful: I'm pleased to have been of service. B ut I'm not sure why you say that the A ct allows the President to prevent a portion of the

20. See infra notes 30-43. 
bill from becoming law. Why isn't it fair to say instead what I thought we agreed on a moment ago - that the bill, in toto, becomes law at the moment the President signs it, but that the A ct permits the President to cancel certain provisions of the law thereafter?

Confident: I'Il tell you why. Because Congress deliberately passed a Line Item Veto A ct. B ecause Congress expressly provided that the President's line item veto "prevents" the canceled provisions from having "legal force or effect." ${ }^{21}$ Because the canceled provisions aren't even to be entered into the U nited States Code. The very aim of the A ct is to allow the President to prevent the canceled provisions - provisions that Congress has passed and that he has signed-from ever becoming law.

D oubtful: Y ou put the case well. However, the A ct expressly provides that the President can exercise the cancellation power only after a bill is "signed into law." ${ }^{22}$ So according to the actual language of the A ct, the President's line item "veto" does not prevent the canceled provisions from ever becoming law. It rescinds them. It terminates or nullifies the legal effect that they obtained when he signed the bill into law. ${ }^{23}$

B ut more fundamentally, you can't really mean that the constitutionality of the A ct turns on the nomenclature Congress used in describing the President's cancellation power. For then even if you were right, and even if this A ct had to be struck down as unconstitutional, it would follow that Congress could constitutionally pass a new line item veto act tomorrow. The new act could be identical to the old in every substantive respect, so long as it had a new name, expressly stated that the signed bill shall be law, called for the publication of the entire signed bill in the U nited States Code-and provided that the President may nonetheless "terminate" (or "suspend") certain of the bill's provisions through the designated cancellation process. A re you prepared to concede that a new line item veto act, with those cosmetic changes, would be constitutional?

Confident: I didn't say that.

21. 2 U .S.C. § 691e(4)(B) (Supp. II 1996).

22. Id. § 691(a) (emphasis added).

23. See id. § 691b(a). 
D oubtful: Well, you must agree that if this A ct is unconstitutional because of its name, and because of the business about the U nited States Code, and because of the language about "prevent[ing]" the canceled provisions from having legal effect, those problems could be easily overcome?

Confident: I suppose so.

Doubtful: So would you object if I proceeded in this discussion by putting aside such problems and by assuming that at the moment when the President signs a bill, the bill becomes law?

Confident: I do object. Y our new line item veto act, even with its new name, and even without the offending language I mentioned before, would still be unconstitutional.

Doubtful: But when I asked you how you knew that the A ct purported to empower the President to prevent the canceled provisions from ever becoming law, you defended your position by referring to the name of the Act, the business about the U.S. Code, and so on. A re you changing your answer?

Confident: I suppose I am not locked into an answer once I have given it.

D oubtful: Certainly you are.

Confident: I am?

D oubtful: $Y$ es. $Y$ ou lose and are now eliminated. However, like the $\mathrm{L}$ ine Item $\mathrm{V}$ eto $\mathrm{A} \mathrm{ct}$, you can be revived with a new name and without the offending language. A II right?

N o-L onger-So-C onfident: G ee, I guess so. Where was I?

D oubtful: $Y$ ou were going to explain why the A ct, even if it had a different name, and even if it stated more expressly than it does now that a signed bill becomes law in toto upon the President's signature, would still be unconstitutional under Section 7. 
N o-L onger-So-C onfident: That's right. There's something wrong with the whole idea of asking whether the bill "became law" at the moment the President signed it.

D oubtful: There is?

No-L onger-So-C onfident: $Y$ es, now that I think it over, the whole question is meaningless. It's transcendental nonsense.

D oubtful: I'm not sure what you mean.

No-L onger-So-C onfident: It's like asking about angels dancing on the head of a pin.

Doubtful: If you say so. But in that case, you must withdraw your constitutional objection to the A ct.

N o-L onger-So-C onfident: W hat?

D oubtful: If there's no meaningful answer to the question of whether the signed bill is law, then you can't object to the A ct on the ground that it stops the signed bill from becoming law. Perhaps you've forgotten, but it was that precise objection of yours that obliged us to try to answer the question of whether the bill became law upon the President's signature. If you now say that the entire question is meaningless, then of course you must also drop your claim that the bill does not become law upon the President's signature.

No-L onger-So-Confident: That's not what I meant at all. I didn't mean that the whole question was meaningless.

D oubtful: I see. What did you mean?

No-L onger-So-Confident: I mean that your way of answering the question is sheer formalism of the worst sort. A piece of paper doesn't "become law" just because the President signs it. If you look at the $L$ ine I tem $V$ eto $A$ ct from a practical and pragmatic standpoint, you immediately see that it is an addition to the lawmaking process, 
not a delegation of power to administer laws already made. U nder the A ct, the President gets to decide that certain provisions of a signed bill are to have no legal effect. No matter how you try to dance around it, the bottom line is that the Act gives the President the power to prevent provisions of a signed bill from becoming the law of the land. Why, no one even knows what actual taxing or spending law is going to govern the country until the President does or doesn't exercise the cancellation power. The very point of Chadha was that the Constitution ordains a procedure that brings the lawmaking process to a close when the procedures of Section 7 have concluded.

D oubtful: Y ou make some good points, but I don't think I can agree with your conclusions. In the first place, to call an argument in this area formalistic is not necessarily to disparage it. Chadha itself may embody a belief that the Constitution's separation of powers rests in part on a healthy formalism, or at least on an adherence to formal processes when the Constitution ordains them. ${ }^{24} \mathrm{~B}$ ut leave that to one side: you add nothing to the argument by labeling the line item veto authority an "addition to the lawmaking process." A ny congressional delegation of authority to the executive or to the judiciary to "fill in the details" necessarily delays the moment at which one can be sure what the full body of legal rules will be beyond the end of the Section 7 process. In every such case what "law is going to govern the country" is uncertain until the officers with delegated authority act. Unless there is some basis for distinguishing the Line I tem $V$ eto A ct from other statutes with this effect, a decision that the $A$ ct is unconstitutional would put in question the entire administrative state.

No-L onger-So-Confident: But there is a basis for distinguishing the A ct. W hen executive or judicial officers fill in the interstices of enacted law, the enacted law remains the law. The $L$ ine I tem $V$ eto A ct gives the President power to stop the relevant provisions from ever becoming law-and I mean from ever really becoming law, from taking real legal effect in the real world.

24. See IN S v. Chadha, 462 U .S. 919, 945-46 (1983) (“Explicit and unambiguous provisions of the Constitution prescribe and define the respective functions of the Congress and of the EXecutive in the legislative process.... These provisions of A rt. I are integral parts of the constitutional design for the separation of powers."). 
D oubtful: Let's think about that. On your view, any statute which creates a conditional rule of law, one that will come into effect if and only if the President makes some future determination, is unconstitutional. For any such statute would do just what you object to in the Line Item V eto Act: it would empower the President to prevent a portion of a bill he has signed from taking real legal effect in the real world. So any such statute would also violate Section 7?

No-L onger-So-Confident: $Y$ es, I guess that follows from what I just said.

D oubtful: W ell, in that event, the Line I tem $V$ eto A ct is not the only casualty. Congress passes conditional statutes all the time. Sometimes Congress declares that certain rules will not come into effect unless an executive agency takes a certain action; sometimes Congress specifically gives the President the power to make a determination, on the basis of which the conditional rules will take effect. ${ }^{25}$ A re these statutes unconstitutional, too? A nd are all the cases that have upheld these statutes wrongly decided?

No-L onger-So-C onfident: G ee, I don't know. M aybe I was wrong to say that any statute is unconstitutional if it gives the President power to prevent portions of a signed bill from becoming the real law of the land.

Doubtful: I think you were wrong. Or at any rate I think it very unlikely that the Supreme Court would knowingly invalidate all condi-

25. A s the district court stated in Synar v. U nited States, "[i]n such cases, the Court classifies Congress's action as legislating in contingency." 626 F. Supp. 1374, 1387 (D.D.C. 1986) (three-judge panel), aff'd sub nom. B owsher v. Synar, 478 U .S. 714 (1986). The district court in Synar cited numerous cases supporting this practice. See Synar, 626 F. Supp. at 1387 (citing U nited States v. R ock R oyal Coop., 307 U .S. 533, 577-78 (1939) (upholding the A gricultural $M$ arketing A greement A ct of 1937, which delegated to the Secretary of A griculture the power to exempt cooperatives from payment of a uniform price to producers of milk); Currin v. Wallace, 306 U .S. 1, 15-16 (1939) (upholding the Tobacco Inspection A ct which delegated to the Secretary of A griculture the power to designate tobacco markets for government inspection and grading); Field v. Clark, 143 U .S. 649, 693 (1892) (holding that Congress had the power to delegate to the President the ability to indefinitely suspend free importation laws against countries which he "deem[ed]" to be unfairly and unequally dealing with the U nited States); The Cargo of the Brig A urora v. U nited States, 11 U.S. (7 Cranch) 382, 388 (1812) (holding that Congress can delegate to the President the power to declare by proclamation that a contingency, upon which the revival of an act is dependent, has occurred)). 
tional statutes, and knowingly reverse all the cases that have previously upheld them, by rejecting the Line Item $V$ eto $A$ ct on these grounds.

No-L onger-So-C onfident: But the Line Item $V$ eto A ct still seems very different to me. It is not like the conditional statutes you refer to. It gives the President power to repeal legislation and to do so piecemeal. It allows him to revise the entire legislative bargain that Congress struck. That's what bothers me about it.

D oubtful: Good. That's an excellent point. U nfortunately, you have now utterly changed your position.

N o-L onger-So-Confident: Can I come back with a new name?

D oubtful: No, your name still suits. Just observe that we are, in large measure, about to leave the terrain covered by Chadha. Perhaps we could put it as follows: Chadha concerned the A rticle I process of lawmaking. The Line I tem $V$ eto $A$ ct raises issues of law unmaking. The true constitutional question raised by the A ct is under what conditions, if any, may Congress vest the President with the power to unmake law that has already been made? The first thing to recognize about this question is that the Constitution does not provide any explicit or formulaic answers to it.

No-L onger-So-Confident: W ell, I don't know that your way of putting it is helpful. A ren't you forgetting that Chadha involved a veto, too? So wasn't Chadha about law unmaking after all?

D oubtful: I don't think so.

No-L onger-So-Confident: $Y$ ou don't? H ow could Chadha involve a veto and not be a case about law unmaking?

D oubtful: B ecause the veto at issue in Chadha was a legislative veto.

N o-L onger-So-C onfident: I don't understand.

D oubtful: I don't blame you. L et me try to explain. A legislative veto is an attempt by Congress to reverse the decisions of executive 
branch (or conceivably even judicial) officers regarding the interpretation or implementation of law, not to change the law they are implementing. There are excellent reasons why Congress should not be permitted to give itself a supervisory role in the execution or adjudication of laws.

No-L onger-So-Confident: But Chadha held that a legislative veto is unconstitutional because it is legislative in nature and therefore has to comply with the Section 7 process. Y ou seem to be saying that a legislative veto is unconstitutional because it is executive or judicial in nature. A re you saying that Chadha was rightly decided but for the wrong reasons?

Doubtful: Let me make a confession. I am of two minds about whether legislative vetoes really are unconstitutional. A nd I mean that literally.

No-L onger-So-Confident: Literally of two minds?

D oubtful: $Y$ es. This is a coauthored work. But I am not calling Chadha into question here, and nothing in my argument turns on a suggestion that Chadha was wrongly decided or even wrongly reasoned. I am saying that, under the Constitution and under Chadha, Congress can intervene in the administration or interpretation of laws only if it proceeds by way of Section $7 .{ }^{26}$ If Congress wants to repeal an administrative regulation, it can certainly do so. If Congress wants to mandate a new interpretation of an old statute, it can do that, too. But it must do so directly- not by turning itself into a supervisory executive or judicial body. It must do so through Section 7 . Congress can involve itself in the interpretation and implementation of law only as a legislature, and therefore a congressional "veto" cannot be constitutional unless it conforms with Section 7. But that is precisely why the Line Item $V$ eto $A$ ct raises no Chadha problem. Chadha makes clear that Congress could not give itself power to rescind any provisions of enacted legislation outside of the Section 7 process. B ut that is because Congress must act only through the Section 7 process. The question is whether the Act is unconstitutional because it gives the President a power to unmake law outside the Sec-

26. See Chadha, 462 U .S. at 950. 
tion 7 process-a power that Congress, under Chadha, clearly could not give itself.

No-L onger-So-C onfident: I think I should thank you again. Surely you've put your finger on the problem now. H ow could Congress give the President a law unmaking power that it does not possess itself?

D oubtful: Y ou have a point. It would seem logically impossible for a legislative body to delegate power that it does not itself possess. But the fact is that every congressional delegation of rulemaking authority to an administrative agency does the same thing: it empowers the administrative agency to promulgate rules of law outside the Section 7 process, which Congress itself could not do. I'm afraid that if we are to keep the administrative state intact, we have to say that Section 7 is not a limit on the legislative powers that Congress can delegate, but only a limit on the process through which Congress can delegate those powers. D o you see what I mean?

\section{N o-L onger-So-C onfident: N ot exactly.}

D oubtful: It's really not complicated. Section 7 applies only to congressional lawmaking. When Congress delegates to officers of the other two branches any of its powers to make or to unmake rules of law, those officers may exercise such delegated powers without going through the Section 7 process. A fter all, that's what executive branch officers do every day, when they exercise their delegated powers to interpret and implement statutory schemes.

N o-L onger-So-C onfident: That seems indisputable.

D oubtful: I think so. So we have answered your question about how Congress could vest the President with the power to rescind unilaterally law outside the Section 7 process even though Congress could not exercise such a power itself. Which means we can finally return to your more important objection.

N o-L onger-So-C onfident: O kay. W hat was it again? 
D oubtful: Y our objection was that the Line I tem V eto A ct authorizes the President to repeal legislation piecemeal and thereby to revise the entire legislative bargain struck by Congress.

No-L onger-So-C onfident: That's right. That's why the A ct is unconstitutional.

\section{REVISING THE LEGISLATIVE BARGAIN}

D oubtful: O nce again, you must permit me to go slowly here. L et me take your objection point by point. A re you saying that Congress may never vest the President with the power to rescind portions of duly enacted law?

No-L onger-So-Confident: Maybe I am. Delegation doctrine may be incredibly broad, but I'm tempted to say that the one thing delegation doctrine cannot permit is delegating to an executive officer the power to simply negate congressionally enacted policy. "Never before," as the district court said in Raines, has a congressional delegation "gone so far as to transfer [to an executive officer] the function of repealing a provision of statutory law." ${ }^{27} \mathrm{H}$ ow can it even be called "executing the law" if the executive simply says no when presented with a congressional directive ${ }^{28}$ Is there some reason why I cannot take this position?

D oubtful: There is indeed, if you count the practice of the nation for almost two centuries as a reason. The R aines court was simply wrong on this point. For example, in 1809, Congress passed a statute allowing the President to suspend commercial non-intercourse laws (an embargo, essentially) upon a determination by him that those laws would no longer serve certain national interests. In a case called The O rono, ${ }^{29}$ no less a figure than J ustice J oseph Story treated the President's power to revoke the embargo provisions as entirely uncontroversial. ${ }^{30}$ Since then, Congress has repeatedly given the President the

27. Byrd v. Raines, 956 F. Supp. 25, 36 (D.D.C. 1997).

28. See Lessig, supra note 6 , at 1661-63 (stating that provisions which allow the President to negate congressional directives fail the non-delegation doctrine just as affirmative executive actions do).

29. 18 F. Cas. 830 (C.C.D. M ass. 1812) (No. 10,585).

30. The question in The Orono was whether the federal government had the lawful authority to seize a schooner for violating an embargo act. Id. at 830 . U nder the Noninter- 
power to terminate provisions of statutory law. ${ }^{31}$ The only limitation added here by modern doctrine is that Congress must have sufficiently limited the President's discretion so as to meet the "intelligibility" requirements of the non-delegation doctrine, ${ }^{32}$ but as the R aines district court correctly noted, that isn't difficult to do. ${ }^{33}$

As to your claim that revoking a law cannot logically be regarded as executing the law, the answer is that if law A expressly authorizes the President to revoke law $B$, a President who exercises this revocation power may not be executing law $B$, but he is certainly executing law A. Indeed, in B owsher v. Synar ${ }^{34}$-the balanced-budget

course A ct of $M$ arch 1,1809 , ch. $24, \S 11,2$ Stat. 530, 531, the President was authorized to "suspend" the embargo with respect to $G$ reat B ritain if B ritain abolished certain of its laws pertaining to $U$ nited States ships. Informed that B ritain had revoked its offending O rders in Council, President $M$ adison exercised his authority under the $A$ ct to issue a proclamation stating that fact and thereby authorizing the resumption of trade with B ritish ports. Madison subsequently learned that his information was erroneous, and he issued a second proclamation that attempted to revive the embargo he had mistakenly suspended. J ustice Story rejected the government's argument that this second proclamation had reinstated the trade ban. The A ct delegated to the President only the power to suspend the embargo; once the President exercised that power, the suspension was necessarily permanent unless Congress itself should pass further legislation. See The O rono, $18 \mathrm{~F}$. Cas. at 830 (discussing the scope of presidential authority under the Nonintercourse A ct and the A ct of J une 28, 1809, ch. 9, 2 Stat. 550). The A ct, wrote J ustice Story, "contains no authority whatsoever to enable the president to revive that act, when once it had been suspended, as to either nation. The authority given is exclusively confined to the revocation of the act." Id.

31. See, e.g., A ct of M ar. 3, 1815, ch. 77, 3 Stat. 224 (authorizing repeal of certain duty laws with "such repeal to take effect in favour of any foreign nation, whenever the President" determines that that nation has abolished its duties); A ct of $M$ ay 31,1830, ch. $219, \S 2,4$ Stat. 425 , 425 (providing that preexisting statutes imposing duties on a foreign nation's vessels "shall be repealed" when "the President determined that that nation had abolished its duties"); A ct of 0 ct. 1, 1890, ch. 1244, § 3, 26 Stat. 567, 612 (authorizing the President to "suspend" provisions on certain conditions); Federal Employees Pay Comparability A ct of 1990, Pub. L. No. 101509, § 529, 104 Stat. 1427, 1430, 1436 (codified at 5 U.S.C. $\S \S 5303(b)(1), 5304 a(a)$ (1994)) (authorizing the President to replace the statutory formula for federal employee pay increases with a formula chosen by the President); D epartment of D efense A uthorization A ct of 1983, Pub. L. N o. 97-252, § 1127(a), 96 Stat. 718, 758 (1982) (codified as amended at 10 U.S.C. § 7309(b) (1994)) (authorizing the President to make exceptions to a ban on foreign construction of military vessels). The Supreme Court discussed and approved the practice-even then a long-standing one- of congressional authorization of the President to "repeal" statutory provisions in Field v. Clark, 143 U .S. 649, 685-87 (1892).

32. The non-delegation doctrine requires "that delegated power include at least roughly intelligible 'standards' to guide the delegated party." TRIBE, supra note 9, at 364.

33. See Byrd v. R aines, 956 F. Supp. 25, 36 (D.D.C. 1997) (citing cases and concluding that a delegation is constitutional as long as "Congress itself articulated 'intelligible principles' by which delegated authority is to be exercised"); see also L oving v. U nited States, 517 U .S. 748, 771 (1996) ("we have since [1935] upheld, without exception, delegations under standards phrased in sweeping terms").

34. 478 U .S. 714 (1986). 
case- the Court expressly held that Congress had vested the Comptroller $\mathrm{G}$ eneral with executive powers when it authorized him to make cuts in appropriations previously enacted. ${ }^{35}$ So long as Congress has explicitly authorized an executive officer to unmake certain laws, and so long as Congress has provided the officer with an "intelligible principle" to guide the exercise of this power, the executive officer will stand as solidly within the confines of delegation doctrine as he does when Congress authorizes him to make law. ${ }^{36}$

No-L onger-So-C onfident: W ait a minute. Y ou said the President had been given the power to "suspend" the law in the statute as issue in The 0 rono. Isn't that different from a power to permanently rescind?

D oubtful: G ood question, but the answer is no. In fact, in The 0 rono, J ustice Story stated that when Congress delegates to the President the authority to "suspend" the operation of a statutory provision, the suspension is necessarily permanent unless Congress has provided some express means through which the President may revive the suspended provision. ${ }^{37}$ The power to "revive" a statutory provision stood for Story on exactly the same basis as the power to suspend one; the President's "authority for this purpose must be derived from some positive law. ${ }^{\prime 38}$ For J ustice Story, the President's suspension power had to be given the same legal effect as a repeal, because "[t]he authority given is exclusively confined to the revocation of the act.". ${ }^{39}$ A nd in a number of later statutes, Congress expressly authorized the President to "repeal" statutory provisions. ${ }^{40}$

No-L onger-So-Confident: I still don't quite see the point of your argument.

D oubtful: Let me try to show you. W ould there be anything constitutionally troubling about a statute that provided the following?:

\footnotetext{
35. See id. at 733.

36. See id. at 720 .

37. See The 0 rono, 18 F. Cas. 830,830 (C.C.D. M ass. 1812) (No. 10,585).

38. Id.

39. Id.

40. See supra note 31 .
} 
In prescribed circumstances, the President may suspend provision $X$ for a time, and at the end of the period, $X$ automatically comes back into effect.

No-L onger-So-C onfident: Of course not. Congress is simply defining how long the suspension it authorizes should be.

D oubtful: I agree. Let me run a couple of variations past you. What do you think about this?

In prescribed circumstances, the President may suspend provision $X$ for a time, and may renew the suspension repeatedly, indeed indefinitely. $X$ comes into effect automatically at the end of the period if the President does not suspend it again.

No-L onger-So-C onfident: I don't see why permitting the President in effect to extend the suspension period makes any difference constitutionally.

D oubtful: N either do I. A nd what about this last hypothetical?:

In prescribed circumstances, the President may suspend provision $X$, with indefinite effect; the President may subsequently revoke the suspension and allow $X$ to come into effect.

No-L onger-So-Confident: Look, I can see as well as you that your last two examples might result in the provisions being unenforced indefinitely: the President could keep renewing the suspension or decline to revoke the suspension, as the case may be. But neither statute would actually permit the President to undo the provision.

Doubtful: I think you've already surrendered the distinction you wanted to maintain. Y ou agree, apparently, that Congress is free either to determine for itself the exact time period that a suspension shall last, or to permit the President the discretion to make the suspension permanent in effect. The L ine Item V eto A ct simply exercises the power to determine an exact time period and in doing so gives the executive less discretion than he would be given in my last two examples. Surely it would be odd to conclude that the problem with the A ct is that it too tightly constrains the power it delegates to the President. ${ }^{41}$

41. But isn't that exactly what R appaport does? See R appaport, supra note 6 , at 772; see also supra notes 16-18 (discussing R appaport's "veto burden" argument). 
No-L onger-So-Confident: $B$ ut there is a distinction between all the statutes to which you refer and the Line I tem V eto A ct. Those statutes authorized the President to cancel their own provisions. ${ }^{42}$ By contrast, when the President cancels a provision under the Line Item $\checkmark$ eto $A$ ct, he exercises power with respect to the provisions of a different law.

D oubtful: A ctually, some of the statutes I referred to gave the President cancellation power over the provisions of another statute. ${ }^{43} \mathrm{~B}$ ut why is that relevant?

N o-L onger-So-C onfident: For the very reason I've already given: by allowing the President to cancel out items from a different law, the L ine I tem V eto A ct permits the President to upset the bargain the lawmaking process reached in shaping that other statute. In other words, the A ct permits the President to change the bargain that C ongress reached in the later bill and that the President accepted when he signed the bill into law.

D oubtful: Good. We arrive, then, at your more important objection. I have heard this objection often, but the truth is that I have difficulty making sense of it. Does "changing the legislative bargain" mean doing something with the law such that some of those congressmen who voted for the bill would not have voted for it?

N o-L onger-So-C onfident: In the case of the Line I tem $\mathrm{V}$ eto $\mathrm{A}$ ct, the President may change the law so much that a majority of congressmen might no longer have voted for it.

D oubtful: Perhaps. But when an administrative agency enacts a new regulation, don't you suppose it likely that some of the congressmen who voted for the underlying law might not have voted for it had they known it would be so interpreted? Indeed, do you suppose an agency

42. See, e.g., 10 U.S.C. § 7309(b) (1994) (authorizing the President to waive the ban on foreign construction of military vessels-a ban established within the same statute-when he unilaterally "determines that it is in the national security interest of the U nited States").

43. See, e.g., A ct of $M$ ay 31, 1830, ch. 219, § 3, 3 Stat. 224 (granting the President the authority to repeal previously enacted duty laws). 
never interprets a statute in a fashion such that a majority of Congress might have voted against the statute, so interpreted?

No-L onger-So-Confident: I suppose that that may sometimes occur. $B$ ut in such a case, I would say that the agency transgressed congressional intent and that its regulation is therefore invalid.

D oubtful: Would you say so? A nd if Congress had specifically and intentionally vested the agency with broad discretion, knowing in advance that the agency might pass the interpretation it did, would you still say so?

No-L onger-So-C onfident: W ell, in that case part of the congressional bargain would have been accepting the risk that the agency might act in the way that it did.

D oubtful: That's just what I think. B ut then you must agree that the President's cancellation power under the Line Item $V$ eto $A$ ct does not "change the legislative bargain" either. The A ct does not interfere with Congress's ability, when passing a future bill, to forbid presidential cancellation of any or all provisions in that bill. If Congress sends the President a taxing and spending bill with provisions subject to the line item veto and doesn't exercise the power to prevent cancellation, it does so knowing that the President may cancel those provisions. Part of the bargain reached through the lawmaking process in such a case was a decision not to prevent the President from exercising the line item veto authority.

No-L onger-So-C onfident: But suppose Congress passes a bill calling for equal foreign aid dollars to I srael and Egypt. The whole point of the package is that Congress is dealing equally with both countries. L et's say that the President signs this bill into law and then cancels out the aid to Egypt. $\mathrm{He}$ has totally undone the legislative bargain and has totally altered the underlying policy that went with it. Congress can't restore its policy choice without mustering a two-thirds vote for it. That's radically different from what any regulatory agency, implementing a congressionally enacted policy, has ever been or would ever be empowered to do. The clause of the A ct permitting future Congresses to shelter tax provisions from the President's line 
item veto ${ }^{44}$ would be completely unavailing, because my Israel-E gypt law involves spending items, not tax items.

D oubtful: I think you may be misunderstanding how the Line Item $V$ eto A ct works. D o you or don't you agree that in the case of the statute you just hypothesized, Congress could, by simply saying so in the bill presented to the President, and by simple majority vote, prevent the President from applying his line item power to the foreign aid grants?

No-L onger-So-Confident: I thought Congress could only shelter tax provisions.

D oubtful: O n the contrary. A ny time Congress wants to couple two spending provisions together, or, for that matter, to make any provision of any bill not subject to the Line Item V eto, it may do so-by simple majority vote. The reason is that a new bill must be signed into law by the President before the Line I tem V eto A ct can apply to it, and if the new bill, just signed into law, modifies the President's cancellation power, the new law supersedes the old and is binding. If the President is presented with a bill to which the Line Item $V$ eto $A$ ct applies, it is because Congress has, by majority rule, decided to send him that bill, with full knowledge and willingness that the line item power may be exercised.

No-L onger-So-Confident: B ut the A ct puts the onus on Congress to take affirmative steps in order to avoid the A ct's applicability in the future.

D oubtful: | don't see why that makes a difference. A || sorts of statutes require Congress to take specific steps in subsequent legislation if it doesn't wish later statutes to be administered in accordance with the earlier. That, indeed, is the very point of "framework statutes." ${ }^{45}$

44. See 2 U .S.C. § 691f (Supp. II 1996).

45. Framework statutes, in this sense, do not simply formulate particular policies but create "a more detailed framework for governmental decisionmaking" by imposing broad congressional requirements across a broad range of specific statutes and policies. G erhard Casper, The Constitutional O rganization of the G overnment, 26 W M . \& M A RY L. REV. 177, 187 (1985). The Line Item $V$ eto $A$ ct is itself codified as an addition to a framework statute, the Congressional Budget and Impoundment Control A ct of 1974, Pub. L. N o. 93-344, 88 Stat. 297 (codified as amended in scattered sections of 2 U.S.C.) (limiting and regulating executive power to de- 
More generally, think about the effect of the well-established rule that later statutes are not to be interpreted as repealing earlier law unless Congress has made the repeal explicit. Congress doesn't violate the Constitution by passing legislation that has a practical effect on how it can later accomplish other goals.

\section{The Separation of Powers}

No-L onger-So-C onfident: I'm not satisfied. I still think that the Line I tem $V$ eto $A$ ct gives the President the power to rewrite legislation. $E$ ven if there's some precedent for this sort of thing, the A ct goes much further than prior statutes. A s the district judge in City of $\mathrm{N}$ ew York put it, while "[t]he line between permissible delegations of rulemaking authority and impermissible abandonments of lawmaking power is a thin one," the Line Item V eto A ct "impermissibly crosses the line [by] surrender[ing] to the President ... . an inherently legislative function, namely, the authority to pick and choose among portions of an enacted law to determine which ones will remain valid." ${ }^{46}$ That's lawmaking, and it violates the general principle of separation of powers to give such lawmaking power to the President.

D oubtful: Excellent. The separation of powers is an excellent objection. But your conclusion is too quick for me. There's an old case that suggests that J ohn M arshall and his colleagues didn't accept your line of thought. In The Brig A urora v. United States, ${ }^{47}$ the argument was made that Congress cannot authorize the President to determine whether an earlier, expired statute's provisions should be partially revived because doing so would be "transfer[ring] the legislative

cline to spend appropriated funds). 0 ther examples of framework statutes include the $\mathrm{N}$ ational E mergencies A ct, Pub. L. N o. 94-472, 90 Stat. 1255 (codified as amended in scattered sections of 50 U.S.C.) (including a provision, codified at 50 U.S.C. $\S 1621(b)(2)$, which states that no statute passed after 1976 supersedes provisions of the A ct unless it does so in "specific terms"), and the National Environmental Policy A ct of 1969, Pub. L. N o. 91-190, 83 Stat. 852 (codified as amended in scattered sections of 42 U .S.C.) (imposing various requirements across a broad range of federal activities and applying those requirements to later-enacted programs). Congress not infrequently exercises its power to prevent the application of framework statute requirements, but of course it must take affirmative steps to do so as long as the framework statute remains in place. See, e.g., National D efense A uthorization A ct for Fiscal Y ear 1996, Pub. L. No. 104-106, § 2833, 110 Stat. 186, 559 (partially exempting certain programs from the requirements of the National E nvironmental Policy A ct).

46. City of $\mathrm{N}$ ew Y ork v. Clinton, 985 F. Supp. 168, 180-81 (D .D.C. 1998).

47. 11 U .S. ( 7 Cranch) 382 (1813). 
power to the President" by giving his action "the force of a law." 48 The Supreme Court made quick work of this reasoning: "[W ]e can see no sufficient reason, why the legislature should not exercise its discretion in reviving the [expired] act ... either expressly or conditionally, as their judgment should direct." ${ }^{49}$ If Congress has the constitutional discretion to grant the President the power to decide, in accordance with conditions Congress has prescribed, that a particular provision of law should go into effect, it is hard to see why Congress doesn't have the discretion to grant the President the power to decide, in accordance with conditions Congress has prescribed, that a particular provision of law should not go into effect.

No-L onger-So-Confident: Sorry, but The Brig Aurora leaves me unimpressed. First, it's a very old case; separation of powers doctrine has evolved a lot since then. More importantly, the situation there was just not comparable to the kind of presidential legislation involved in the Line Item $V$ eto A ct. A llowing the President to revive an embargo in matters directly pertaining to foreign policy is not remotely analogous to allowing the President to pick and choose, out of every single omnibus appropriations bill, which spending items will or will not be the law of the land. Y ou don't want to confront it, but the L ine I tem $V$ eto A ct basically turns the President into a superdraftsman, blue-penciling the budget and tax laws of the nation in accordance with his, not Congress's, policy choices.

D oubtful: A II right, then let's return to a much more recent case very much on point: B owsher v. Synar. ${ }^{50}$ R emember that Bowsher also involved a statute which vested a supervisory budget-cutting authority in an officer whose decisions were to have been implemented directly by the executive branch. Indeed, the Balanced Budget A ct of $1985^{51}$ went considerably farther than does the Line Item $V$ eto $A$ ct in creating what you call a super-legislator outside Congress: the Comp-

48. Id. at 386 (1813) (argument of counsel). The issue in The B rig A urora concerned the successor embargo act to the one J ustice Story considered in The O rono, 18 F. Cas. 830 (C.C.D. $M$ ass. 1812). The later act authorized the President to revive the (expired) provisions of the earlier trade ban against either Britain or France if the other country recognized A merican claims about neutral shipping. The lawfulness of the A urora's seizure depended on the legal effect of the President's action.

49. The B rig A urora, 11 U.S. (7 C ranch) at 388.

50. 478 U.S. 714 (1986).

51. 2 U .S.C. $\S 901$ et seq. (1982 \& Supp. III 1985). 
troller General was empowered to go through the entire federal budget, program by program, and make cuts in every single one of them as he saw fit. ${ }^{52} E$ ven so, the Bowsher Court did not hold that vesting such power in an executive officer was unconstitutional as such. On the contrary, the Court held that the Comptroller General could not constitutionally exercise this power because the Comptroller $\mathrm{G}$ eneral was not executive enough (he was subject to discharge by Congress and was thus found to be an agent of the legislative branch). ${ }^{53} \mathrm{~B}$ owsher almost conclusively stands for the proposition that a statute delegating discretionary budget-cutting authority delegates executive powers.

No-L onger-So-Confident: A s I recall B owsher, wasn't the Comptroller $\mathrm{G}$ eneral basically a ministerial officer, required to make prescribed budget cuts without exercising any policymaking judgment of his own?

D oubtful: A nother good question, but the Bowsher Court did not think so and made a contrary finding part of the holding of the case. The Court rejected the claim that the Comptroller General's duties under the A ct were "essentially ministerial. ${ }^{.54}$ The Court expressly found that the "Comptroller General must exercise judgment" and "interpret the provisions of the A ct," and that he had "the ultimate authority to determine the budget cuts to be made." ${ }^{55}$ Indeed, the B owsher Court stated that this discretionary aspect of the Comptroller $\mathrm{G}$ eneral's duties was part of what made those duties executive, so that the Comptroller $\mathrm{G}$ eneral ought not to have been removable by Congress. ${ }^{56} \mathrm{G}$ iven B owsher, I really don't think you can object to the Line Item V eto Act on the ground that it vests in the executive branch a power to make selective budget-cutting decisions-or, as you put it, to "pick and choose among portions" of an appropriations law "and determine which ones will remain valid."

52. See id. at 717,731 (describing the Comptroller G eneral's powers under the Balanced B udget and E mergency D eficit Control A ct of 1985).

53. See id. at 727-32.

54. Id. at 733-34.

55. Id. at 732-33.

56. See id. at 733. 
No-L onger-So-C onfident: I think you're doing something tricky with B owsher. To begin with, the B owsher Court didn't expressly say that the Balanced Budget A ct would have been constitutional if the Comptroller $\mathrm{G}$ eneral had not been removable by Congress.

D oubtful: True, but none of the Court's reasoning is dictum either. The finding that the Comptroller $G$ eneral had been vested with executive power was essential to the holding of the case. A nd that finding pretty much negates any claim that the Line I tem $V$ eto $A$ ct vests the President with "legislative" powers, don't you think?

No-L onger-So-C onfident: N o, I don't think so.

D oubtful: Why not?

N o-L onger-So-C onfident: W ell, I'm embarrassed to say.

D oubtful: D on't be silly.

No-L onger-So-C onfident: I think I'm getting confused about the whole doctrine of separation of powers.

D oubtful: Y ou're in good company. Can you tell me what it is that's confusing?

No-L onger-So-Confident: Didn't B owsher also hold that if Congress itself had done exactly the same program-by-program budget cutting that it asked the Comptroller General to do, Congress would have been acting legislatively?

D oubtful: $Y$ es, in effect.

No-L onger-So-C onfident: W ell, how can it be that an action is "executive" if performed by the Comptroller General, but "legislative" if performed by Congress?

D oubtful: Y ou are asking a deep and dark question. Do we really have to enter into that cave? 
No-L onger-So-C onfident: I think we do. O ne thing we know for sure is that the Constitution "refutes the idea that [the President] is to be a lawmaker." ${ }^{57}$ D espite B owsher, I just don't see how we can keep the President from being a lawmaker if we allow the President to exercise program-by-program rewriting of congressional policy-the kind of rewriting that would clearly be "legislative," under Chadha and even B owsher, if Congress itself sought to do it.

D oubtful: Would it help if I told you that the Court's more recent separation of powers cases, such as M orrison ${ }^{58}$ and even more clearly $\mathrm{M}$ istretta ${ }^{59}$ have largely repudiated the attempt to decide which powers are purely executive or essentially legislative? A Ithough earlier cases pursued this taxonomic approach, the problem was always that the analysis seemed to change depending on which officer was taking the action at issue. Y ou just pointed this out with respect to B owsher, but it was equally true in Chadha, where the Court said that Congress's decision about whether a person did or did not fall within the category "deportable alien" was legislative in character, but that the A ttorney G eneral's virtually identical decision was executive in character $^{60}$ In the more recent cases, the Court has stopped trying to classify particular powers as uniquely executive, legislative, or judicial. The point is not to achieve a "hermetic division between the Branches," ${ }^{61}$ but to ensure that no one branch achieves too much unilateral power. ${ }^{62}$ I think the Line Item V eto A ct fits comfortably into the new regime. Does that solve your problem?

\section{No-L onger-So-C onfident: $\mathrm{N} O$.}

D oubtful: I didn't think it would. B ut tell me why not.

No-L onger-So-Confident: Because I know all about the old debate between "formalism" and "functionalism" in separation of powers

\footnotetext{
57. Y oungstown Sheet \& Tube Co. v. Sawyer, 343 U .S. 579, 587 (1952).

58. M orrison v. O Ison, 487 U .S. 654 (1988) (upholding the constitutionality of the E thics in Government A ct).

59. M istretta v. U nited States, 488 U .S. 361 (1989) (upholding the constitutionality of the U nited States Sentencing Commission).

60. See INS v. Chadha, 462 U .S. 919, 953 n.16 (1983).

61. M istretta, 488 U .S. at 382.

62. See id.
} 
doctrine ${ }^{63}$ and I don't accept M orrison and M istretta as wholesale repudiations of the old "formalist" cases. For one thing, M etropolitan Washington A irport A uthority, ${ }^{64}$ decided after those cases, is just as formalist as any of the older cases.$^{65} \mathrm{~A}$ nd for another, I think the formalist cases may have been right.

D oubtful: $Y$ ou leave us no choice, then. Y ou seem insistent that we enter into the debate between formalism and functionalism in separation of powers doctrine.

No-L onger-So-Confident: I think we have to. The Line Item V eto A ct, for all practical purposes, gives the President substantial lawmaking power. Its hard to believe that that could be constitutionally acceptable. I want to know how that result is constitutionally acceptable. This is the kind of case that requires us to go back to first principles.

D oubtful: A re you prepared to conclude that the entire administrative state is unconstitutional?

No-L onger-So-Confident: $\mathrm{N}$ o. I didn't mean to go back that far into first principles.

D oubtful: G ood. B ut perhaps we had better say that the constitutionality by and large of the administrative state will be one of our first principles.

\section{No-L onger-So-C onfident: O kay.}

D oubtful: Perhaps it will also be helpful to clarify the debate we are trying to resolve. I will understand the so-called "formalist" position

63. For commentary in and on this debate, see D ean A Ifange, J r., The Supreme Court and the Separation of Powers: A Welcome Return to Normalcy?, 58 G E O. W A SH. L.J . 668 (1990); Stephen L. Carter, From Sick Chicken to Synar: The E volution and Subsequent D e-E volution of the Separation of Powers, 1987 BY U L. REV . 719; Stephen L. Carter, The Independent Counsel M ess, 102 H A RV. L. R Ev. 105 (1988); L ee S. L ieberman, M orrison v. O Isen: A Formalistic Perspective on Why the Court Was Wrong, 38 A M. U . L. R E V. 313 (1989)

64. 501 U.S. 252 (1991).

65. See id. at 274-77 (holding, on separation of powers grounds, that it would be unconstitutional for members of Congress to serve on the A irport A uthority's review board). 
to hold that the correct approach to separation of powers cases is for a court to look at the governmental action at issue, to decide whether that governmental action is legislative, executive or judicial in nature, and then to make sure that only legislators are performing legislative actions, only executive officers are performing executive actions, and so on. Is that fair?

N o-L onger-So-C onfident: I think so.

D oubtful: A nd I will understand the "functionalist" position to hold that the proper approach is not to make these conceptual determinations, but rather to favor overlapping, concurrent jurisdictions among the branches and to ensure that no one branch is vested with too much unilateral power. A II right?

N o-L onger-So-C onfident: A II right.

D oubtful: So that we might call formalism a separation of powers approach and functionalism a checks and balances approach. Do you follow me?

No-L onger-So-Confident: $Y$ es, and that's why I've always preferred formalism. Call me old-fashioned, but I think there should be a separation of powers approach to separation of powers cases.

D oubtful: Perhaps so, but what if I now said that the administrative state effectively puts an end to the whole debate between formalism and functionalism in the area of separation of powers? W hat if I said that you can't be a separation of powers formalist and accept the constitutionality of executive officers performing legislative functions?

No-L onger-So-Confident: I wouldn't be happy with that conclusion at all. There are a lot of formalist cases out there, and I'm not prepared to accept that it follows as a logical matter from the administrative state that they were all wrongly decided. Chadha held that legislative vetoes were unconstitutional because they were legislative in nature and therefore had to comply with Section $7 .{ }^{66}$ B owsher held that Congress could not retain a removal power over officers exer-

66. See IN S v. Chadha, 462 U.S. 919, 953 (1983). 
cising executive functions. ${ }^{67}$ Y oungstown held that the President could not unilaterally order his subordinates to take over A merican steel mills because his doing so was essentially presidential lawmaking. ${ }^{68}$ $M$ etropolitan Washington held that M embers of Congress cannot exercise executive powers. ${ }^{69}$ I told you before: I think these cases may have been rightly decided, and I can't believe that the constitutionality of the administrative state somehow dictates a contrary result.

D oubtful: K now what? I think they may have been rightly decided too.

No-L onger-So-C onfident: Y ou do?

D oubtful: I really do.

No-L onger-So-C onfident: W ell, then, don't go defending the Line I tem $V$ eto $A$ ct by invoking $M$ orrison and $M$ istretta. If you accept the formalist cases, you have to admit that the A ct vests in the President an essentially legislative function.

D oubtful: O n the contrary. D idn't we see only a moment ago that the Court in B owsher held-as a formalist matter-that the power to exercise budget-cutting discretion over the entire range of federal spending programs was an executive function?

N o-L onger-So-C onfident: D amnation. That's where I got confused in the first place. How can that function be executive when we know that if Congress performed the very same function, it would be legislative? I mean, if we accept the formalist cases, how can a given governmental action be legislative when Congress performs it, but executive when the executive performs it? And if we can't solve that problem, why isn't the administrative state unconstitutional after all? Now I'm totally perplexed again.

67. See B owsher v. Synar, 478 U .S. 714, $732-34$ (1986)

68. See Y oungstown Sheet \& Tube C o. v. Sawyer, 343 U .S. 579, 588-89 (1952).

69. See M etropolitan Washington, 501 U.S. at 277. 
D oubtful: I may have an answer to all your riddles. But I have to tell you in advance that I can't agree with you about dismissing M orrison and $\mathrm{M}$ istretta. I think they may have been rightly decided too.

N o-L onger-So-C onfident: But you can't. U nless you mean they were rightly decided but wrongly reasoned at a deep level. Is that what you mean?

D oubtful: N o. I mean that I accept the checks and balances approach to separation of powers questions. A nd I do so in part because otherwise the administrative state would indeed be unconstitutional.

No-L onger-So-Confident: B ut you said you thought the formalist cases might have been rightly decided too. I don't understand.

Doubtful: Everyone seems to think that "formalism" and "functionalism," or the separation of powers and checks and balances approaches, are mutually exclusive. I don't.

No-Longer-So-Confident: But they are mutually exclusive. If you took a rigorous separation of powers approach to $\mathrm{M}$ istretta, the case would have come out the other way, wouldn't it?

D oubtful: I imagine so.

No-L onger-So-C onfident: But you think Mistretta was rightly decided?

D oubtful: I do.

No-L onger-So-Confident: But that means you reject the formalist, separation of powers approach.

D oubtful: D efinitely not.

N o-L onger-So-C onfident: This is maddening.

D oubtful: Sometimes the light can be maddening if a person has spent his life in a cave. 
N o-L onger-So-C onfident: $\mathrm{O}$, put up or shut up.

D oubtful: Sorry. Here's the key to the riddle. I believe in the formalist separation of powers approach to separation of powers cases when $\mathrm{M}$ embers of Congress are the governmental actors whose reaching or overreaching is in question.

N o-L onger-So-C onfident: W hat? I've never heard of such a thing.

D oubtful: I understand that, but it entirely solves all the difficulties at once. Look at the great formalist cases. In Chadha, as you noted, $\mathrm{M}$ embers of Congress were trying to decide whether an individual alien was deportable under established law. ${ }^{70}$ In B owsher, a congressional removal power was at stake. ${ }^{71}$ In $M$ etropolitan Washington, it was $\mathrm{M}$ embers of Congress again, trying to sit on an airport authority board. ${ }^{72}$ The same point can be about other formalist cases, too. ${ }^{73}$ Congressmen cannot exercise executive or judicial powers, but executive and judicial officers may exercise legislative powers. Hence the administrative state is perfectly constitutional, but courts must continue to exercise formalist separation of powers vigilance whenever Congress tries to give its own $\mathrm{M}$ embers any powers outside the A rticle I, Section 7 lawmaking process.

No-L onger-So-Confident: But what possible basis is there for drawing such a distinction between Congressmen and the officials of other branches?

D oubtful: The best possible basis: the command of the Constitution. In A rticle I, Section 6, the Constitution expressly provides that no M ember of Congress may serve as an O fficer of the $U$ nited States. ${ }^{74}$ A nd in A rticle II, Section 2, the Constitution excludes Congress from

70. See Chadha, 462 U.S. at 953.

71. See Synar, 478 U .S. at 732-34.

72. See M etropolitan Washington, 501 U .S. at 277.

73. See, e.g., Buckley v. V aleo, 424 U .S. 1 (1976) (holding that the A ppointments Clause forbids Congress from appointing executive officers); M yers v. U nited States, 272 U.S. 52 (1926) (invalidating a statutory provision conditioning the President's power to remove an executive officer on the consent of the Senate).

74. See U.S. CONST. art. I, $\S 6, \mathrm{cl} .2$ ("no Person holding any 0 ffice under the U nited States, shall be a $\mathrm{M}$ ember of either H ouse during his Continuance in O ffice"). 
appointing $\mathrm{O}$ fficers of the $\mathrm{U}$ nited States. ${ }^{75} \mathrm{~A} \mathrm{n}$ " $\mathrm{O}$ fficer of the $\mathrm{U}$ nited States" is a federal official exercising any significant executive or judicial powers. ${ }^{76}$ It follows that $\mathrm{M}$ embers of Congress cannot exercise such powers; nor can they appoint themselves to do so. There is an excellent reason why the Constitution should prevent Members of Congress from serving as officers. The reason comes back to checks and balances.

When an executive or judicial officer exercises legislative power, he can do so only through an authority delegated by Congress and with monies appropriated by Congress. Moreover, when executive officers perform lawmaking functions in administrative agencies, they act not only within confines set forth by Congress, but subject to review by the judiciary. ${ }^{77} \mathrm{~B}$ ut if $\mathrm{M}$ embers of C ongress were able to give themselves the power to execute, interpret, or adjudicate their own laws, then Congress would have no check on its powers at all. The administrative state is full of checks and balances guarding against an accumulation of excessive unilateral power in the President. But without the distinction on which I insist and which A rticle I, Section 6 polices, Congress could arrogate to itself unilateral power.

The Constitution erects no similar bar against executive or judicial officers. Of course they cannot serve as M embers of Congress, but there is no bar against an executive officer holding a judicial office (remember Chief J ustice $\mathrm{M}$ arshall) or performing lawmaking duties if such duties have been duly delegated to the officer by Congress.

I think that with this rule in mind, you should be able to solve all your perplexities about modern separation of powers doctrine.

75. SeeU.S. Const. art. II \& 2, cl. 2:

[The President] shall nominate, and by and with the A dvice and Consent of the Senate, shall appoint ... all other $O$ fficers of the $U$ nited States, whose A ppointments are not herein otherwise provided for, and which shall be established by Law: but the Congress may by Law vest the A ppointment of such inferior O fficers, as they think proper, in the President alone, in the Courts of $L$ aw, or in the H eads of $D$ epartments.

76. See Buckley, 424 U.S. at 125-26. O fficials of other governments sometimes may exercise authority under the laws of the U nited States-think of state officials administering "cooperative federalism" programs and the like-but their actions in doing so do not implicate federal separation of powers concerns and they appropriately are not subject to the requirement of appointment in accordance with A rticle II. See The Constitutional Separation of Powers B etween The President and Congress, 200 p. O ff. L egal Counsel 26-27 ( $M$ ay 7, 1996).

77. See IN S v. Chadha, 462 U.S. 919, 953 n.16 (1983). 
No-L onger-So-C onfident: I still have at least one. Y ou neglected to mention Y oungstown. ${ }^{78}$ In Y oungstown, it was the President-not the Congress- whose actions were at issue, and the opinion of the Court concluded that the President had violated the Constitution by acting legislatively. ${ }^{79}$

D oubtful: Which is why the official opinion of the Court in Youngstown has been so entirely superseded in authority by Justice Jackson's much better reasoned concurrence. ${ }^{80}$ It's hard to even make sense of the idea that the President acted "legislatively" by seizing the nation's steel mills. Justice Jackson had it right: the President acted unconstitutionally in Y oungstown because he acted in defiance of congressional directives, without any sustainable claim in the Constitution that he could act unilaterally in such a matter. Indeed, J ustice Jackson's opinion in Y oungstown, which has been so influential, may be said to be the very cornerstone of the anti-unilateral-power, checks and balances approach I have been describing. The President's steel seizure was unconstitutional not because he acted "legislatively," which Presidents may do when so authorized by Congress, but because he had acted in such a way as to circumvent or ignore any possible check from Congress. ${ }^{81}$

No-L onger-So-C onfident: Well, you are too many for me. I can't object to your solution to the separation of powers debate, but I'm not entirely sure I accept it, either. Can you just tell me how things play out for the $\mathrm{L}$ ine I tem $\mathrm{V}$ eto $\mathrm{A}$ ct?

D oubtful: $\mathrm{H}$ ere is how I think things stand. First, if you accept unquestioningly the formalist cases, your objection to the A ct will primarily be that the President has been made into a lawmaker, but this objection is substantially undermined by Bowsher, a formalist case holding that the power to go through the federal budget and make discretionary, program-by-program cuts is executive in nature. ${ }^{82}$

78. See Y oungstown Sheet $\&$ T ube Co. v. Sawyer, 343 U .S. 579, 588-89 (1952).

79. See id. at 588-89 (1952).

80. See id. at 592-655 (J ackson, J ., concurring); see also, e.g., B owsher v. Synar, 478 U .S. 714, 721 (1986) (citing J ackson concurrence).

81. See $Y$ oungstown, 343 U .S. at 640.

82. See Synar, 478 U .S. at 733. 
Second, if you accept unquestionably the functionalist cases, or if you accept my solution to the debate between formalism and functionalism in separation of powers cases, you will not have much of an objection either, because then the only question will be whether the A ct "disrupts the proper balance between the coordinate branches" or whether it "prevents [the affected] B ranch from accomplishing its constitutionally assigned function" ${ }^{83}$ - tests that are not hard to satisfy and that, I think, the A ct quite easily satisfies. Have we come, then, to the end of our conversation?

No-L onger-So-Confident: $\mathrm{No}$, not yet. I admit that my efforts to bring the Act down on formalist grounds have not succeeded. But I'm not prepared to agree with you on your last point. E ven if I accept the checks and balances approach, and the more nebulous standards from Morrison and M istretta, I think there is still a case to be made against the Line Item $V$ eto $A$ ct. The $A$ ct vests unilateral power in the President to make budget-cutting decisions. It prevents Congress from accomplishing its constitutionally assigned function of determining the content of federal law.

Doubtful: I don't agree. Congress's ability to determine the content of federal law is entirely unimpaired, including its power to present the President with a take-it-or-leave-it taxing or spending bill. Moreover, the Act is fairly tightly circumscribed. The fact that the President can exercise his line item veto only within the first five days after signing a bill into law is an important restriction. 0 therwise, the President would have a weapon he could wield against individual congressmen at any time, by threatening to cancel their favorite spending measures if they don't do his bidding. The limited category of provisions to which the line item power applies is another important restriction. A nd, Congress is perfectly free to forbid the exercise of the line item veto as to any particular provision, or any particular bill. True, to do so requires the mustering of enough political will to enact legislation, but that's the case any time Congress delegates power to the executive and doesn't include an automatic sunset provision. A nd anyway, even if you put more weight than I think you should on the Act's "imposition" on Congress, it is clear from the

83. M istretta v. U nited States, 488 U .S. 361, 382 (1989). 
modern cases that mere interference with the freedom of action of one of the branches doesn't violate the separation of powers. ${ }^{84}$

\section{DRA WING The Line A T the PRESIDENT'S SignatURE}

No-L onger-So-C onfident: But you keep-you're not-I don't know how you did it, but you've argued your way to a manifestly unconstitutional conclusion. Look, would you agree that the following would be unconstitutional?:

U pon being presented with a taxing or spending bill, the President may, before signing the bill or vetoing it, strike out any provisions of the sort covered by the Line I tem $V$ eto $A \mathrm{ct}$, under the procedure set forth in that A ct. The President may then sign into law the bill not including those provisions that have been struck out.

D oubtful: That certainly sounds like it's unconstitutional. B ut that's because it would probably violate Section 7, and I thought we finished with Section 7 a long time ago.

No-L onger-So-Confident: $Y$ ou concede that my pre-signature line item veto act is unconstitutional?

\section{D oubtful: Y es.}

No-L onger-So-Confident: Then it should be obvious to you that the actual Line Item $V$ eto $A$ ct is unconstitutional. The only difference between my hypothetical and the $A$ ct is a matter of a few days.

D oubtful: No, that's not the only difference. U nder your hypothetical statute, the President is given the power to prevent portions of a signed bill from ever becoming law, and that consequence-as you pointed out earlier - would violate the "shall ... become a L aw" Ianguage of A rticle I, Section 7.

N o-L onger-So-C onfident: I thought we rejected formalism!

\footnotetext{
84. See, e.g., id. at 380-82; Nixon v. A dministrator of G en. Servs., 433 U .S. 425, 441-43 (1977) (embracing a "flexible approach" to separation of powers questions and rejecting a requirement of absolute independence).
} 
D oubtful: O n the contrary, I think I've told you that I am an A rticle I formalist.

No-L onger-So-C onfident: $B$ ut this is formalism without any function. Y ou admit that my hypothetical statute would be functionally identical to the actual Line I tem V eto A ct. W hat kind of respect is it for the Constitution's commands to turn those commands into empty shells? If the Constitution forbids giving the President a line item veto before he signs a bill into law, and if the actual $A$ ct is functionally identical to giving the President such a power, surely the Act must be unconstitutional too.

D oubtful: I didn't admit that your hypothetical statute and the actual A ct are functionally identical. Consider it carefully. The Line Item $\checkmark$ eto $A$ ct does not allow the President to exercise his cancellation power on a bill until that bill is law. A s we have seen, this means that if Congress wants to depart from the L ine I tem $V$ eto A ct-if it wants to modify the President's line item powers or abolish them entirely as to a particular bill-it can always do so by simple majority vote of both H ouses. The President cannot exercise his line item power until he has signed the new bill into law. If Congress has provided in the new bill that the $L$ ine I tem $V$ eto $A$ ct does not apply, or that it applies only with certain modifications, Congress's new will is now the law. The new bill must become law before the L ine I tem $V$ eto A ct comes into play, and the new law supersedes the old. W e've already seen the decisive importance of this aspect of the Line Item V eto A ct. Because the A ct operates only after the President has signed a bill, the A ct allows Congress to escape its terms, by simple majority vote, as to any subsequent legislation.

$B$ ut if the President is given a pre-signature line item veto, this result no longer holds. If the President could cancel provisions of a later bill before the new bill became law, he could ignore any countermanding provisions of the new bill, which would not be law at the time he applied his blue pencil to them. That is a crucial functional difference, and it gives powerful support for drawing a constitutional line between a pre-signature and a post-signature line item veto.

No-L onger-So-Confident: I think there's a hole in your reasoning. $M$ y hypothetical line item statute could achieve the same result even if it still gave the President the cancellation power before signing the 
bill into law. J ust imagine that my hypothetical line item statute goes on to provide that it shall not apply to any bill that says that the line item power shall not apply to it. N ow the two situations are identical again.

D oubtful: No, they're not. U nfortunately, your hypothetical statute could not include the provision you just tried to add to it. For your new pre-signature line item act would in effect give binding force to what Congress says in a new bill, before the bill has become law. A s our discussion of Chadha and the separation of powers should have made clear, such a provision would violate the Constitution. U nder your new hypothetical statute, Congress would in essence have created for itself a bicameral legislative veto, a congressional power to countermand execution of a law in a particular case, merely by passing a bill not yet signed by the President. A line item statute that gave the President a pre-signature cancellation power could not have its application made conditional on Congress's decision in a subsequent bill about whether to have it apply.

No-L onger-So-Confident: Can't I argue that my hypothetical statute wouldn't create a legislative veto, but would simply be defining one of the conditions under which the President could exercise the presignature cancellation power?

D oubtful: Y ou could, but you should lose that argument. No one thinks that Congress can evade Chadha simply by redefining a legislative veto as an affirmative condition on the executive's exercise of authority. That really would make the principle of Chadha formalism without any function, except as a drafting instruction to Congress about how to write statutes permitting its $\mathrm{M}$ embers to exercise powers outside the bounds of Section 7. The effect of your statute is the same, regardless of how you characterize it: the two H ouses of Congress get to decide, on their own, not to permit the President to exercise a power otherwise available to him. Except for the constitutionally unimportant fact that your hypothetical involves action by both $\mathrm{H}$ ouses, not just one, its constitutional vice is identical to the problem in Chadha.

N o-L onger-So-C onfident: Say, I just had an idea. Y ou don't suppose the $L$ ine I tem $V$ eto $A$ ct is constitutional, do you? 